\title{
VILLAMOS JÁRMÜ HIBRID ENERGIATÁROLÓ RENDSZERÉNEK SZABÁLYOZÁSA
}

\section{CONTROL OF AN ELECTRIC VEHICLE HYBRID ENERGY STORAGE SYSTEM}

\author{
Ferencz János, ${ }^{1}$ Kelemen András, ${ }^{2}$ Imecs Mária ${ }^{3}$ \\ 1 Kolozsvári Müszaki Egyetem, Villamosmérnöki Kar, Doktori Iskola, Kolozsvár, Románia, \\ janos_ferencz@yahoo.com \\ 2 Sapientia Erdélyi Magyar Tudományegyetem, Marosvásárhelyi Kar, Villamosmérnöki Tanszék, Marosvá- \\ sárhely, Románia, kandras@ms.sapientia.ro \\ ${ }^{3}$ Kolozsvári Müszaki Egyetem, Villamosmérnöki Kar, Doktori Iskola, Villamos Gépek és Hajtások Tanszék, \\ Kolozsvár, Románia, Maria.Imecs@emd.utcluj.ro
}

\begin{abstract}
In electric vehicles battery life can be prolonged by using hybrid energy storage systems (HESS), which combine high energy density batteries with supercapacitors, characterized by high power density. This paper deals with the control of electronic power converters from an active parallel HESS. The load of the HESS is the electrical motor drive of an electric vehicle. The interfaces between the DC-link and the power sources are four-phase bidirectional DC-DC converters driven in current control mode, based on the current references supplied by an active parallel HESS power distribution algorithm. We present a rule-based fuzzy energy management algorithm for a HESS powered electric vehicle and its simulation in MATLAB/Simulink ${ }^{\circledR}$ environment using the Quasi-Static Simulation (QSS) and Fuzzy Logic toolboxes. Also, simulation results in driving and regenerative braking operation modes of the electric vehicle are presented.
\end{abstract}

Keywords: hybrid energy storage systems, energy management algorithm, bidirectional 4-phase DC-DC converter, power distribution control structure.

\section{Összefoglalás}

A hibrid energiatároló rendszerek (HETR) az energiaforrásként használt akkumulátorok élettartamának a meghosszabbítására szolgálnak. A tanulmány egy olyan HETR energiamenedzsmentjét vizsgálja, amely elsődleges energiaforrásként egy nagy energiasűrüségü lítium-ion akkumulátorcsomagot, illetve másodlagos energiaforrásként egy nagy teljesítménysűrűségű szuperkondenzátor-csomagot tartalmaz. A HETR terhelése egy villamos autó villamos hajtása. Az energiatárolók és az egyenáramú közbenső kör közötti interfészek áramszabályozott, kétirányú, négyfázisú, átlapolásos vezérlésű DC-DC (egyenáramú) áramirányítók, amelyek áramreferenciáit az aktív párhuzamos HETR energiamenedzsment-algoritmusa határozza meg. A dolgozat bemutat egy fuzzy szabályalapú HETR energiamenedzsment-algoritmust, valamint annak szimulációját MATLAB/Simulink ${ }^{\circledR}$ környezetben, a QSS (Quasi Static Simulation) és Fuzzy Logic könyvtárak felhasználásával a villamos jármủ menet- és regeneratív fékezési üzemmódjaiban.

Kulcsszavak: hibrid energiatároló rendszer, energiamenedzsment algoritmus, kétirányú 4-fázisú DC-DC áramirányító, teljesítménymegosztó szabályozási struktúra. 


\section{Bevezetés}

A villamos járművek fejlődése eredményezte a hibrid energiatároló rendszerek (HETR) elterjedését. Ezáltal az energiaforrásként használt akkumulátor élettartama meghosszabbítható, mivel a HETR másik energiatárolója megkíméli az akkumulátort a káros teljesítménysokkoktól. Amikor a jármű villamos meghajtásához vagy fékezéséhez viszonylag nagy pillanatnyi teljesítményre van szükség, akkor a villamos gép által felvett vagy leadott teljesítmény megosztását a szuperkondenzátor és az akkumulátor között a HETR energiamenedzsment-algoritmusa a szuperkondenzátor irányába tolja el [1].

Gyorsításkor, amikor hirtelen meg kell növelni a járművet meghajtó villamos gép teljesítményét, akkor a HETR ezt az energiát a szuperkondenzátorból biztosítja, mentesítve az akkumulátort a teljesítménysokktól. Hasonlóképpen a jármű visszatápláló regeneratív fékezésénél, amikor ugyancsak hirtelen viszonylag nagy pillanatnyi teljesítményen a villamos gépből áramló energiát kell eltárolni, akkor a HETR ezt az energiát a szuperkondenzátorba fogja betölteni [2].

A fuzzy-szabályalapú HETR energiamenedzsment-algoritmusnak (EMA) három bemenete (SOC, SOE és $\left.P_{\text {el_req }}\right)$ és két kimenete van $\left(P_{\text {req_SC }}\right.$ és $P_{\text {req_BAT }}$ ), mint ahogyan az 1. ábrán is látható.

A fuzzy szabályalapú HETR EMA az akkumulátor töltöttségi állapotából (SOC - „State of Charge”) és a szuperkondenzátor energiaállapotából (SOE - „State of Energy”), valamint a $P_{\text {el_req }}$ igényelt vagy a visszatáplálandó pillanatnyi villamos teljesítményből, ami a jármű meghajtásához, illetve a fékezéséhez szükséges, kiszámítja a szuperkondenzátor $P_{\text {req_SC }}$ és az akkumulátor $P_{\text {req_BAT }}$ előírt pillanatnyi teljesítményét.

\section{A fuzzy szabályalapú HETR energia- menedzsment-algoritmus}

Az akkumulátor töltöttségi állapota ( $S O C$ ) és a szuperkondenzátor energiaállapota (SOE) csak a $0-100 \%$ pozitív tartományban változhat (tel- jesen lemerült állapotban $0 \%$, teljesen feltöltött állapotban 100\%). A fuzzy szabályalapú HETR EMA bemeneteként megjelenő $P_{\text {el req válto- }}$ zó megfelel annak a villamos teljesítménynek, amely egy adott pillanatban szükséges a villamos jármű meghajtásához vagy fékezéséhez. Ez a $P_{\text {el_req }}$ pillanatnyi teljesítmény a dolgozatban alkalmazott konvenció szerint a jármű gyorsításakor pozitív, illetve a jármű visszatápláló regeneratív fékezési állapotában (lassításkor) negatív. A fuzzy-következtető rendszer által számított $P_{\text {req_sc }}$ teljesítmény előírt érték részaránya az összteljesítményből megnövekszik a jármű gyorsítási, illetve regeneratív fékezési állapotában. A dolgozatban bemutatott fuzzy-szabályalapú HETR EMA menedzsment-algoritmust a MATLAB ${ }^{\circledR}$ „Fuzzy Logic Designer” alkalmazása segítségével terveztük meg. A fuzzy-következtető rendszer az akkumulátor töltési állapotához (SOC) három háromszög alakú tagsági függvényt rendel [3, 4, 5].

A szuperkondenzátor energiaállapotához (SOE) ugyancsak három háromszög alakú tagsági függvényt rendeltünk. A kért villamosteljesítmény $\left(P_{\text {el_req }}\right)$ esetében összesen hat háromszög-függvényt alkalmaztunk, mivel az negatív értékeket is felvehet (a visszatápláló regeneratív fékezés folya- mán). A fuzzy-következtető rendszer kimenete a szuperkondenzátor által biztosítandó pillanatnyi teljesítmény $\left(P_{\text {req_sc }}\right)$, amely hat háromszög-függvénnyel van lefedve, és a jármű gyorsításakor pozitív, illetve a regeneratív fékezési üzemmód folyamán negatív.

A HETR Mamdani típusú fuzzy szabályalapú EMA-nak összesen 54 szabályát fogalmaztunk meg, amelyek úgy határozzák meg a kért szuperkondenzátor-teljesítményt, hogy az akkumulátor ne károsodjék.

A 2. ábrán a tervezett fuzzy EMA által az 54 logikai szabály alapján kiszámított szuperkondenzátor-teljesítmény $\left(P_{\text {req_sc }}\right)$ látható. A számítások során figyelembe voltak véve a fent említett ki- és bemeneti tagsági függvények. A bemutatott felületdiagramot a MATLAB ${ }^{\circledR}$ „Fuzzy Logic Designer” alkalmazás segítségével generáltuk. Bemenetként

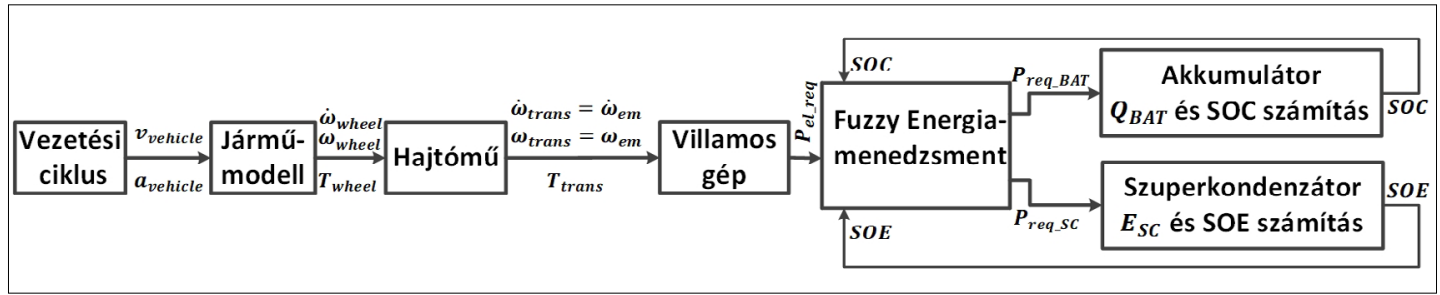

1. ábra. A fuzzy-szabályalapú HETR energiamenedzsment-algoritmus szimulálási tömbvázlata 
az igényelt pillanatnyi teljesítmény relatív értéke $\left(P_{\text {el_req }}{ }^{*}\right)$ és a szuperkondenzátor energiaszintje $(S O E)$ jelenik meg, kimenetként pedig annak a teljesítménynek a relatív értéke $\left(P_{\text {req_sc }}{ }^{*}\right)$, amelyet a HETR-nek a szuperkondenzátorból kell biztosítania. A diagramon az algoritmus által hozott döntések eredményeit szemléltetjük két szélsőséges esetben. Példaként először vegyük azt az esetet, amikor hirtelen megnő a pozitív $P_{\text {el_req }}$ teljesítmény, mely a jármű meghajtásához szükséges, és a szuperkondenzátor töltöttségi szintje magas. Ekkor az akkumulátor károsodásának elkerülése céljából a szuperkondenzátor nagy pillanatnyi teljesítményen fogja biztosítani a szükséges (pozitív) energiát. Ez a példa a 2. ábra felületdiagramja felső részében „Példa1”-es szöveggel van jelölve.

Egy másik sajátos eset, amikor a jármű regeneratív fékezési állapotában hirtelen megnő a negatív $P_{\text {el_req }}$ teljesítmény, aminek következtében az akkumulátornak és a szuperkondenzátornak energiát kell eltárolnia.

Ebben az esetben, ha a szuperkondenzátor töltöttségi szintje alacsony, akkor a generált villamos energia túlnyomó részét képes eltárolni, és az akkumulátor igénybevétele csak a generált teljesítmény töredékére korlátozódik. Ez az eset a 2. ábra felületdiagramján „Példa2” szöveggel van megjelölve. A felületdiagram a fuzzy-szabályalapú döntéshozatal eredményét az akkumulátor 50\%-os töltöttségi szintje (SOC) esetére szemlélteti.

Az igényelt pillanatnyi teljesítmény relatív értéke $\left(P_{\text {el_req }}{ }^{*}\right)$ és a szuperkondenzátorból biztosítandó teljesítmény relatív értéke $\left(P_{\text {req_sc }}{ }^{*}\right)$ a $P_{N}=16 \mathrm{~kW}$ névleges értékhez van viszonyítva.

\section{Az energia-menedzsment algoritmu- sának a hajtásrendszerbe helyezett szimulációja}

A fuzzy szabályalapú HETR EMA-nak a szimulációja egy villamos géppel meghajtott jármű modelljével történt, MATLAB/Simulink ${ }^{\circledR}$ környezetben. A hajtásrendszer modelljének az első tömbje (lásd az 1. ábrát) a vezetési ciklus, mely generálja a jármű sebesség és gyorsulás értékeit, városi környezetben, körülbelül 20 perc időtartamig.

A szimulált vezetési ciklus „NEDC” (New European Driving Cycle) típusú és a Simulink® „QSS” (Quasi Static Simulation) könyvtára tartalmazza. Azért választottuk ezt a vezetési ciklust, mert folyamatos indításokat és megállásokat tartalmaz, ami alatt tesztelni lehet a teljesítménymegosztást a jármű gyorsítási és lassítási állapotaiban [6].

A villamos jármű szimulációs modelljének a következő tömbje a jármű matematikai modellje, amely a vezetési ciklus lineáris sebesség és gyorsulás értékeit átszámítja a jármű kerekére, vagyis forgó mozgássá alakítja [6, 7].

A járműmodell kimenetei a kerék szögsebessége és szöggyorsulása, valamint a kerékre ható forgatónyomaték. A jármű kerekének a szögsebességét $\left(\omega_{\text {wheel }}\right)$, illetve szöggyorsulását $\left(d \omega_{\text {wheel }} / d t\right)$ a jármü lineáris sebességéből ( $v_{\text {vehicle }}$ ), illetve gyorsulásából $\left(a_{\text {vehicle }}\right)$ lehet kiszámítani az alábbi összefüggések alapján:

$$
\begin{aligned}
& \omega_{\text {wheel }}=\frac{v_{\text {vehicle }}}{r_{\text {wheel }}} ; \\
& \frac{d \omega_{\text {wheel }}}{d t}=\frac{a_{\text {vehicle }}}{r_{\text {wheel }}}
\end{aligned}
$$

ahol az $r_{\text {wheel }}$ a kerék sugara.

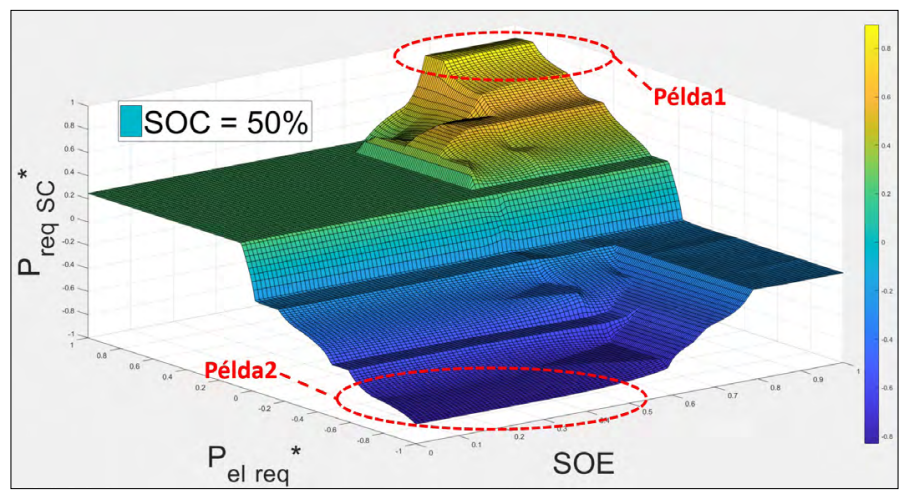

2. ábra. A fuzzy-szabályalapú HETR energiamenedzsment-algoritmus felületdiagramja SOC=50\%-ra, ahol független változóként az igényelt pillanatnyi teljesítmény relatív értéke $\left(P_{\text {el_req }}{ }^{*}\right)$ és a szuperkondenzátor energiaszintje (SOE), függő változóként pedig a szuperkondenzátorból biztosítandó teljesítmény relatív értéke $\left(P_{\text {req_sc }}{ }^{*}\right)$ szerepel. 
A kerékre ható forgatónyomaték kiszámításához a járműre ható külső erőket szükséges meghatározni. A súrlódási erő $\left(F_{\text {friction }}\right)$ és a légellenállási erő $\left(F_{a i r}\right)$ mindig ellentétes irányú a jármű haladási irányával, és ezeket az alábbi összefüggésekkel lehet kiszámolni:

$$
\begin{aligned}
& F_{\text {friction }}=\mu m g \cos \alpha ; \\
& F_{\text {air }}=\frac{1}{2} \rho C_{d} A_{\text {front }} v_{\text {vehicle }}{ }^{2} ; \\
& F_{\text {gravity }}=m g \sin \alpha,
\end{aligned}
$$

ahol $\mu$ a gördülési súrlódási együttható, $m$ a jármű tömege, $g$ a gravitációs gyorsulás, $\rho$ a levegő sürüsége, $C_{d}$ a légellenállási tényező, $A_{\text {front }}$ a jármű homlokfelülete, amely merőleges a jármű menetirányára, és $\alpha$ az emelkedő, illetve a lejtő szöge.

Ezeknek az erőknek az összege

$$
F_{\text {load }}=F_{\text {friction }}+F_{\text {air }}+F_{\text {gravity }}
$$

az az $F_{\text {load }}$ erő, ami állandósult állapotban, amikor a sebesség állandó, terheli a járművet. Tehát a (3)-ban megadott erők hozzák létre a villamos gép tengelyén az úgynevezett terhelőnyomatékot.

Abban az esetben, ha a jármű nem sík terepen, hanem egy lejtőn vagy egy emelkedőn közlekedik, akkor $\alpha \neq 0$ és a jármüre egy $F_{\text {gravity }}$ potenciális aktív-jellegű erőösszetevő is hat, a $(2$, c) szerint, mely fékező vagy meghajtó hatású, attól függően, hogy a jármű felfele halad az emelkedőn $(\alpha>0)$, vagy lefele a lejtőn $(\alpha<0)$. Mindkét esetben aktív, viszont az utóbbi esetben a mozgás irányába hat, és nem „terhelni”, hanem hajtani fog (regeneratív fékezés).

Ha figyelembe vesszük a gyorsulásából származó tehetetlenségi erőt,

$$
F_{\text {inertial }}=m a_{\text {vehicle }}
$$

a jármű dinamikus modellje, amikor a motor szögsebessége változik $\left(\omega_{e m} \neq c t\right.$.), a következő egyenlettel írható fel:

$$
F_{\text {traction }}=F_{\text {inertial }}+F_{\text {load }}
$$

ahol $F_{\text {traction }}$ a keréken kifejtett húzóerő.

$\mathrm{Az}$ 1. ábra alapján a „Vezérlési ciklus” nevü tömb generálja a sebesség és gyorsulás pillanatértékét, amiből a „Jármü-modell” nevű tömb kiszámítja a jármű kerekére ható $T_{\text {wheel }}$ nyomatékot, amit a hajtómű kell kifejtsen, hogy a villamos gép gyorsítson vagy fékezzen.
A jármű kerekére ható nyomaték a következő összefüggéssel számítható ki:

$$
T_{\text {wheel }}=F_{\text {traction }} r_{\text {wheel }}
$$

A szimuláció során a jármű tömegének $m=750$ $\mathrm{kg}$, a jármű homlokfelületének $A_{\text {front }}=1,8 \mathrm{~m}^{2}$, a légellenállási együtthatónak $C_{d}=0,22$ és a súrlódási együtthatónak $\mu=0,008$ paraméterértékeket választottunk.

Az 1. ábrán a szimulációs struktúra következő számítási tömbje a hajtómű (sebességváltó), ami a járműmodell-tömb bemeneti szögsebességét $\left(\omega_{\text {wheel }}\right)$ és szöggyorsulását, valamint a kerékre ható meghajtó forgatónyomatékot $\left(T_{\text {wheel }}\right)$ átszámolja a mechanikai áttétarány $\left(a_{\text {trans }}\right)$ segítségével a motor tengelyére.

A motortengely szögsebessége $\left(\omega_{\text {trans }}=\omega_{e m}\right)$ és szöggyorsulása ( $\left.d \omega_{\text {trans }} / d t\right)$ az alábbi összefüggésekkel számíthatók ki:

$$
\begin{aligned}
& \omega_{\text {trans }}=a_{\text {trans }} \omega_{\text {wheel }} ; \\
& \frac{d \omega_{\text {trans }}}{d t}=a_{\text {trans }} \frac{d \omega_{\text {wheel }}}{d t}
\end{aligned}
$$

A hajtómű bemenetén a motor tengelyére ható $T_{\text {trans }}$ terhelőnyomatékot a kerék $T_{\text {wheel }}$ nyomatékból számítjuk át, figyelembe véve az $a_{\text {trans }}$ mechanikai áttétel értékét, a $P_{\text {loss }}$ mechanikai teljesítményveszteséget, amely a fogaskerekek súrlódásából származik és egy megadott szögsebességhatár fölött jön számításba, valamint a forgó részek további veszteségeit (például a csapágyakét, beleértve a villamos gépét is) az $\eta_{\text {trans }}$ hatásfok által.

A villamos gép tengelyére ható nyomatékokat előrehaladáskor $\left(\omega_{e m}>0\right)$ az alábbi összefüggésekkel lehet meghatározni:

- motor üzemmódban az I. síknegyedben

$$
T_{\text {trans }}=\frac{T_{\text {wheel }}+\frac{P_{\text {loss }}}{\omega_{\text {trans }}}}{a_{\text {trans }} \eta_{\text {trans }}} \text {, ha } T_{\text {wheel }}>0 \text {; }
$$

- regeneratív fékezéskor a II. síknegyedben

$$
T_{\text {trans }}=\frac{T_{\text {wheel }}+\frac{P_{\text {loss }}}{\omega_{\text {trans }}}}{a_{\text {trans }}} \eta_{\text {trans }} \text {, ha } T_{\text {wheel }}<0 \text {. }
$$

A hajtóművet a következő adatokkal szimuláltuk: a mechanikai áttétel aránya $a_{\text {trans }}=3$ a fogaskerekek súrlódásból származó teljesítményveszteség $P_{\text {loss }}=50 \mathrm{~W}$ és a további veszteségeknek megfelelő hatásfok $\eta_{\text {trans }}=98 \%$.

A villamos jármű következő szimulációs tömbje a meghajtására szolgáló villamos gép, amely - a mozgásegyenlet alapján - a $T_{e m}$ tengelynyomatékot kell kifejtse 


$$
T_{\text {em }}=T_{\text {trans }}+J_{m} \frac{d \omega_{e m}}{d t},
$$

ahol $\omega_{\text {em }}=\omega_{\text {trans }}$ a motor szögsebessége és $J_{m}$ a forgó testeknek a motor tengelyére redukált tehetetlenségi nyomatéka (beleértve a rotorét is), melynek az értékét a szimulációkban 0,0025 kg m²-re becsültük.

A villamos gép kapcsain a $P_{\text {el_req }}$ villamos teljesítményt a tengelynyomatékból és a rotor szögsebességéből számítjuk ki. Ezt előrehaladáskor $\left(\omega_{e m}>0\right)$ az alábbi összefüggésekkel lehet meghatározni:

- motor üzemmódban az I. síknegyedben

$$
P_{e l_{r e q}}=\omega_{e m} T_{e m} \frac{1}{\eta_{e m}\left(\omega_{e m}, T_{e m}\right)} ;
$$

- regeneratív fékezéskor a II. síknegyedben

$$
P_{e l \_r e q}=\omega_{e m} T_{e m} \eta_{e m}\left(\omega_{e m}, T_{e m}\right) \text {. }
$$

ahol a $\eta_{e m}$ a motor villamos (tekercs-) veszteségeinek és mágneses (vas-) veszteségeinek megfelelő hatásfok.

Az I-es síknegyedben a jármű villamos gépje hajt, a II-es síknegyedben fékez. A szimulációkban a motor $\eta_{e m}=f\left(\omega_{e m}, T_{e m}\right)$ hatásfokát a Simulink ${ }^{\circledR}$ „QSS” könyvtár „eta_EM_map” adatstruktúrájának az igénybevételével vettük figyelembe [6].

Az akkumulátort és a szuperkondenzátort a QSS könyvtár „Battery” és „Supercapacitor” modelljeivel szimuláltuk [6]. Ezeknek a bemenetei a $P_{\text {req_BAT }}$ és $P_{\text {req_SC }}$ pillanatnyi igényelt villamos teljesítmények (lásd az 1. ábrát), melyeket az EMA energiamegosztással határoz meg az akkumulátor energiaállapotának (SOC) és a szuperkonden- zátor töltöttségi szintjének ( $S O E$ ) a függvényében, a7. aláhbi össz.efüggések értelmében:

$$
\begin{aligned}
& S O C=\frac{Q_{B A T}}{Q_{B A T \_N O M}} ; \\
& S O E=\frac{E_{S C}}{E_{S C_{-} N O M}} ; \\
& P_{\text {el_req }}=P_{\text {req_BAT }}+P_{\text {req_SC }}
\end{aligned}
$$

A $\left(11\right.$, a) és a $\left(11\right.$, b)-ben $Q_{B A T}$ az akkumulátorban tárolt töltésmennyiség, illetve $E_{S C}$ a szuperkondenzátorban tárolt energia pillanatértéke.

A $\left(11\right.$, c)-ben a $P_{\text {req_sc }}$ szuperkondenzátor-teljesítményt az energiamenedzsment-algoritmus (EMA) határozza meg a megadott fuzzy-logikai szabályok, továbbá a járműmodellből származó, a jármű meghajtásához szükséges $P_{\text {el_req }}$ villamos teljesítmény figyelembevételével.

A szimuláció során az akkumulátor kezdeti töltöttségi állapota a névleges tárolókapacitás $\left(Q_{B A T_{-} N O M}=100 \mathrm{Ah}\right) 80 \%$-a, valamint a $C_{S C}=48 \mathrm{~F}-\mathrm{os}$ kapacitású szuperkondenzátor kezdeti energiaszintje a névleges érték $\left(E_{S C_{-} N O M}=1215 \mathrm{~kJ}\right.$, $U_{S C_{-} N O M}=225 \mathrm{~V}$ ) $90 \%$-a volt.

A fuzzy-szabályalapú HETR EMA-t Simulink ${ }^{\circledR}$ környezetben a „Fuzzy Logic Controller” nevü modellel szimuláltuk, amelynek a be- és kimenetei relatív mennyiségek, ezért a bemeneten a $P_{\text {el_req }}$ teljesítményt a $P_{N}=16 \mathrm{~kW}$ alapértékkel osztjuk, viszont a kimeneten ezzel szorzunk, mivel a $P_{\text {req_sc }}$ és $P_{\text {req_BAT }}$ teljesítményeket kW-ban kell továbbítanunk az „Akkumulátor” és „Szuperkondenzátor” tömbök felé.

A 3. ábra a) diagramja a NEDC vezetési profil által generált sebességet, a b) a gyorsulást jeleníti

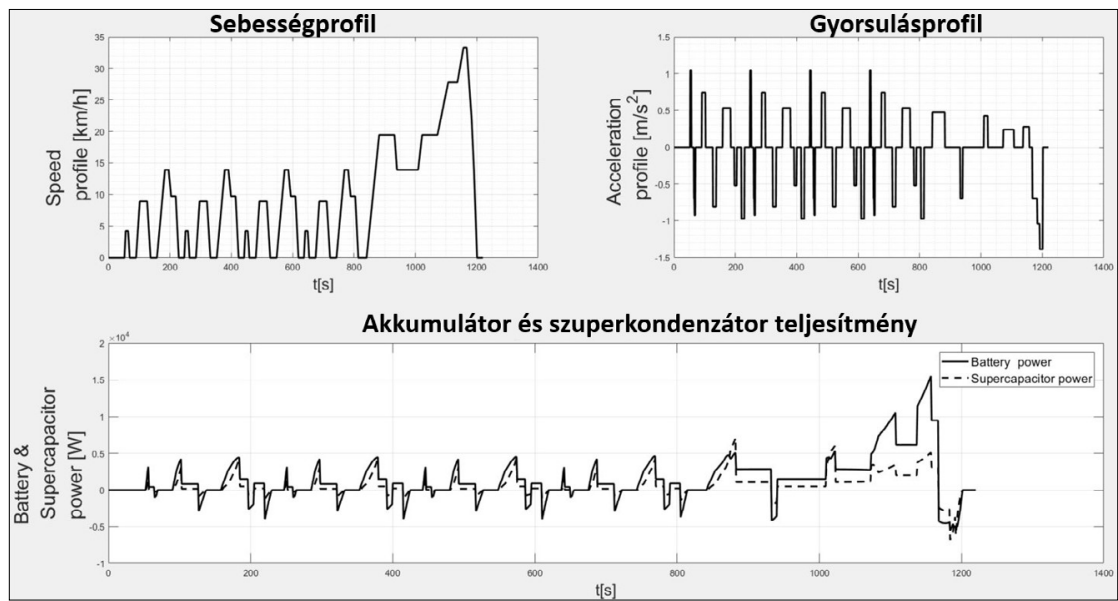

3. ábra. Szimulációs eredmények a megosztott teljesítmény szemléltetésére: a) az NEDC sebesség vezetési profilja; b) az NEDC gyorsulási profilja; c) a megosztott teljesítmény: az akkumulátor (folytonos vonal) és a szuperkondenzátor (szaggatott vonal) által biztosított teljesítmény. 
meg, míg a c) diagram az energiamenedzsment EMA számításai alapján az akkumulátor és a szuperkondenzátor közötti teljesítménymegosztást ábrázolja.

A 3. ábra c) diagramján észrevehető, hogy a teljes, körülbelül 20 perces vezetési ciklus alatt a pillanatnyi villamos teljesítmény több mint felét a HETR a szuperkondenzátorból biztosítja. Az akkumulátorból kért teljesítmény számítása $\left(P_{\text {req_BAT }}\right)$ a $(10, \mathrm{~b})$ és $(10, \mathrm{c})$ összefüggés alapján történt.

A vezetési profil alatt a szuperkondenzátor kezdeti feszültsége 90\%-ról körülbelül 45\%-ra csökkent.

A 4. ábra a) diagramjain a fuzzy szabályalapú EMA visszacsatolt bemenetei láthatók: SOC az akkumulátor töltöttségi állapota és $S O E$ a szuperkondenzátor energia állapota, melyeket az NEDC vezetési ciklus profilja határoz meg.

Továbbá a 4. ábra b) diagramján a fuzzy szabályalapú EMA-nak az a bemenete látható, amely a jármű meghajtásához szükséges $P_{\text {el_req }}$ összteljesítmény érték, amit a HETR-nek biztosítania kell és amit a villamos gép modelltömbje a $(10, c)$ alapján számol ki. A 4. ábra c) görbéje a fuzzy-szabályalapú EMA által kiszámolt $P_{\text {req_sc }}$ szuperkondenzátor teljesítmény relatív értéke, amely segítségével elkerülhető az akkumulátorkárosodás.

A fuzzy szabályalapú EMA hangolása a bemeneti és kimeneti tagsági függvények paramétereinek a módosításával, továbbá a logikai szabályok változtatásával történt. Abban az esetben, amikor a szuperkondenzátor energiaállapota (SOE) 10\% alá csökken, az EMA a jármű meghajtásához szükséges összteljesítményt az akkumulátorból biztosítja.

\section{A HETR energiaáramlás-szabályozása}

A nemzetközi szakirodalomban a két elektromos energiaforrással és egy terheléssel rendelkező HETR-nek teljesítményelektronikai szempontból hét különböző topológiája lelhető fel [8].

Az egyik ilyen HETR változat az 5. ábrán szemléltetett aktív párhuzamos topológia, amely esetében mindkét energiaforrás kétirányú DC-DC áramirányítón (egyenáram mind a bemeneten, mind a kimeneten) keresztül csatlakozik az egyenáramú közbenső körhöz (EÁKK) [9].

A párhuzamos topológia „,aktív" jelzője arra vonatkozik, hogy a HETR mindkét energiaforrásának a villamos mennyiségeit (áram, feszültség, teljesítmény) szabályozni lehet, a felépítésében szereplő két kétirányú áramirányító segítségével.

Ezekkel az áramirányítókkal szabályozni lehet a teljesítménymegosztást a lítium-ion akkumulátor és a szuperkondenzátor között, melyekkel a villamos jármű hajtásrendszerét betápláljuk.

Kétirányú DC-DC áramirányító azért szükséges, mivel a HETR mechanikai teljesítmény leadásakor energiaforrásként, viszont visszatápláló regeneratív fékezési üzemmódban energiatároló rendszerként müködik.

A kétirányú energiaáramlásnak tulajdonítható, hogy működés közben a villamos jármű az akkumulátorról tölteni tudja a szuperkondenzátort annak alacsony energiaszintű állapotában.

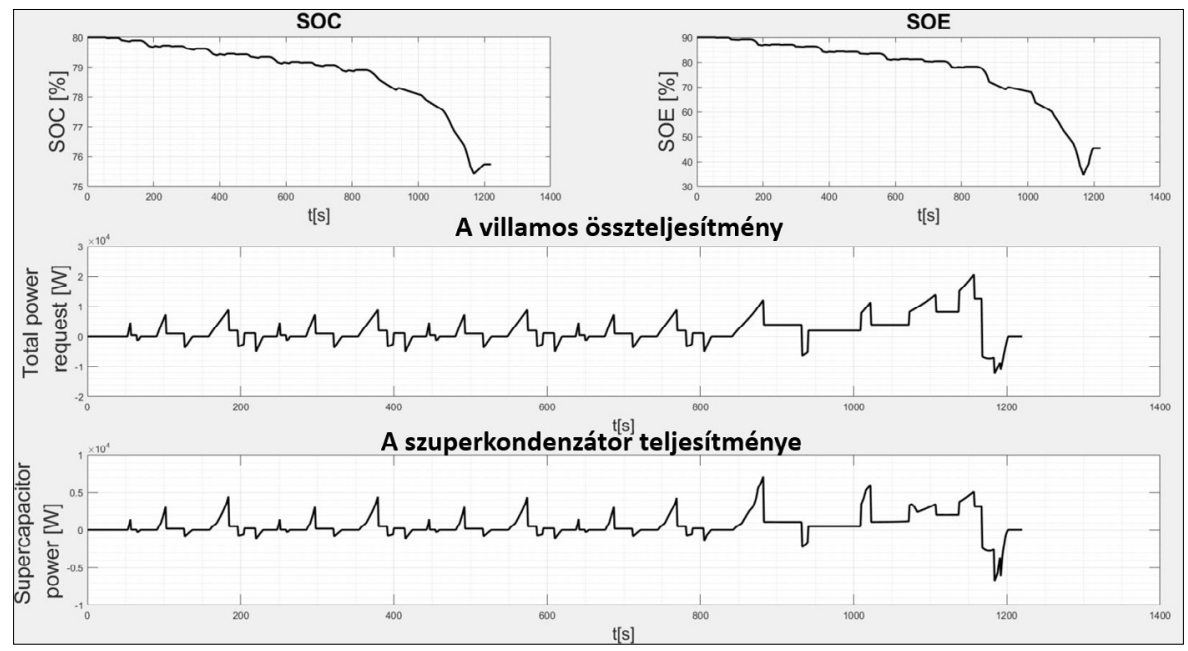

4. ábra. A fuzzy-szabályalapú EMA szimulációs eredményei:

a) SOC az akkumulátor töltöttségi állapota; b) SOE a szuperkondenzátor energiaállapota;

c) a villamos összteljesítmény $P_{\text {el_req; }}$;) a szuperkondenzátor-teljesítménye $P_{\text {req_sc. }}$. 


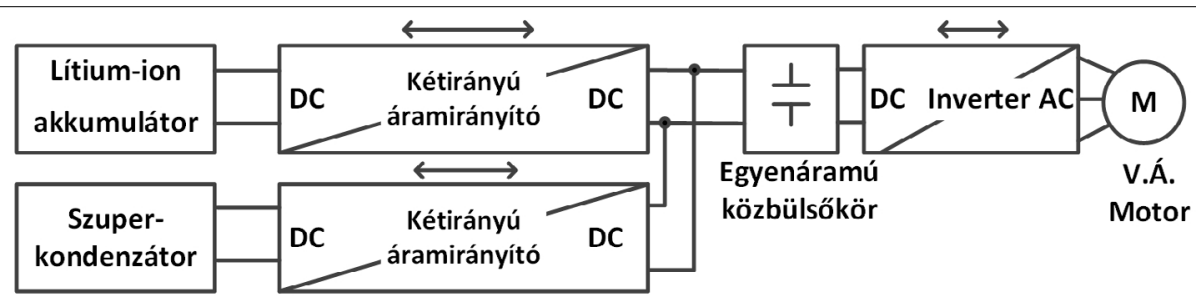

5. ábra. Az aktív párhuzamos hibrid energiatároló rendszer (HETR) tömbvázlata

\section{A kétirányú DC-DC áramirányító}

Az aktív párhuzamos HETR két kétirányú áramirányítót tartalmaz. Mindkettőnek a terhelésoldali kimenete ugyanarra az egyenáramú közbenső körre (EÁKK) van kapcsolva, melyet gyakorlatilag egy kondenzátor alkot, és melyről terhelésként a jármű villamos hajtásrendszerét tápláljuk (5. ábra) [8].

Mivel a gyakorlatban a a villamos járművek HETR-ének akkumulátora és szuperkondenzátora nincs egymástól galvanikusan leválasztva, ezért kétirányú, galvanikus leválasztást nem biztosító magas hatásfokú DC-DC áramirányító került alkalmazásra [10].

A 6. ábrán bemutatott kétirányú, 4-fázisú átlapolásos vezérlésű (4FL) angolul „Interleaved Four Phase”-nek nevezett DC-DC áramirányító négy, kettőnként mágnesesen csatolt tekercset tartalmaz [10].

A kétirányú 4FL DC-DC áramirányító nyolc MOSFET teljesítménytranzisztort tartalmaz, amelyek páronként négy ágat alkotnak. Minden ág felső tranzisztorának rácsjele komplementáris az ág alsó rácsjelével ( $S_{1 H}$ komplementárisa az $S_{1 L}$-nek stb.).

A mágneses csatolást a tekercsek méretének a csökkentése és az áramirányító hatásfokának a növelése teszi célszerűvé [11, 10].

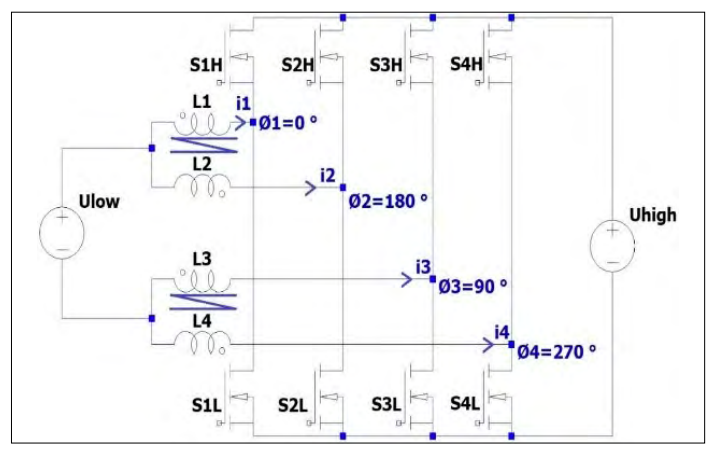

6. ábra. A kétirányú 4-fázisú átlapolásos vezérlésü $D C-D C$ áramirányító topológiája [10]
A 4-fázisú DC-DC áramirányító csatolt tekercseinek a szimulált átlapolt áramait $\left(i_{1}, i_{2}, i_{3}\right.$, és $\left.i_{4}\right) \mathrm{a}$ 7. ábrán szemléltetjük.

A 6. ábrán az ágak mellett feltüntetett villamos-szögek a 8. ábrán látható logikai vezérlőjelek fáziseltolását jelentik az 1-es ág alsó tranzisztorának $S_{1 L}$ vezérlőjeléhez képest (ezek $T_{s} / 4, T_{s} / 2$, illetve $3 T_{s} / 4$ időbeli eltolásoknak felelnek meg, ahol $T_{s}$ az áramirányító kapcsolási periódusa) [10].

Fontos megjegyezni, hogy a kétirányú 4FL DCDC áramirányító működéséhez elengedhetetlen, hogy az akkumulátor, vagy a szuperkondenzátor felőli, bemeneti oldali feszültségforrás $\left(U_{l o w}\right)$ feszültsége alacsonyabb legyen, mint az EÁKK-felőli, kimeneti oldali feszültségforrásé $\left(U_{h i g h}\right)$.

A kétirányú 4FL DC-DC áramirányító szimulációja MATLAB/Simulink® környezetben történt. A csatolt tekercsek $L_{1}, L_{2}, L_{3}, L_{4}$ induktivitását az alábbi összefüggéssel határoztuk meg [11]:

$$
L_{1}=L_{2}=L_{3}=L_{4}=\frac{U_{\text {low }} * D_{M A X}}{\Delta I_{L} * f_{S}},
$$

ahol $U_{\text {low }}$ a kétirányú 4FL DC-DC áramirányító bemeneti alacsony feszültsége, $D_{M A X}$ az áramirányító meghajtása során alkalmazott legnagyobb kitöltési tényező, $\Delta I_{L}$ a maximális áramváltozás a tekercsben egy kapcsolási periódus $\left(T_{S}\right)$ alatt, illetve $f_{s}$ az áramirányító kapcsolási frekvenciája.

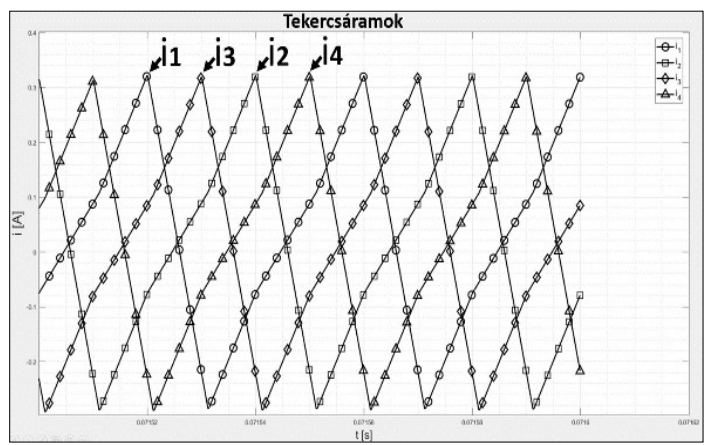

7. ábra. A 4-fázisú DC-DC áramirányító átlapolt bemeneti áramai az alacsony feszültségü oldalon. 


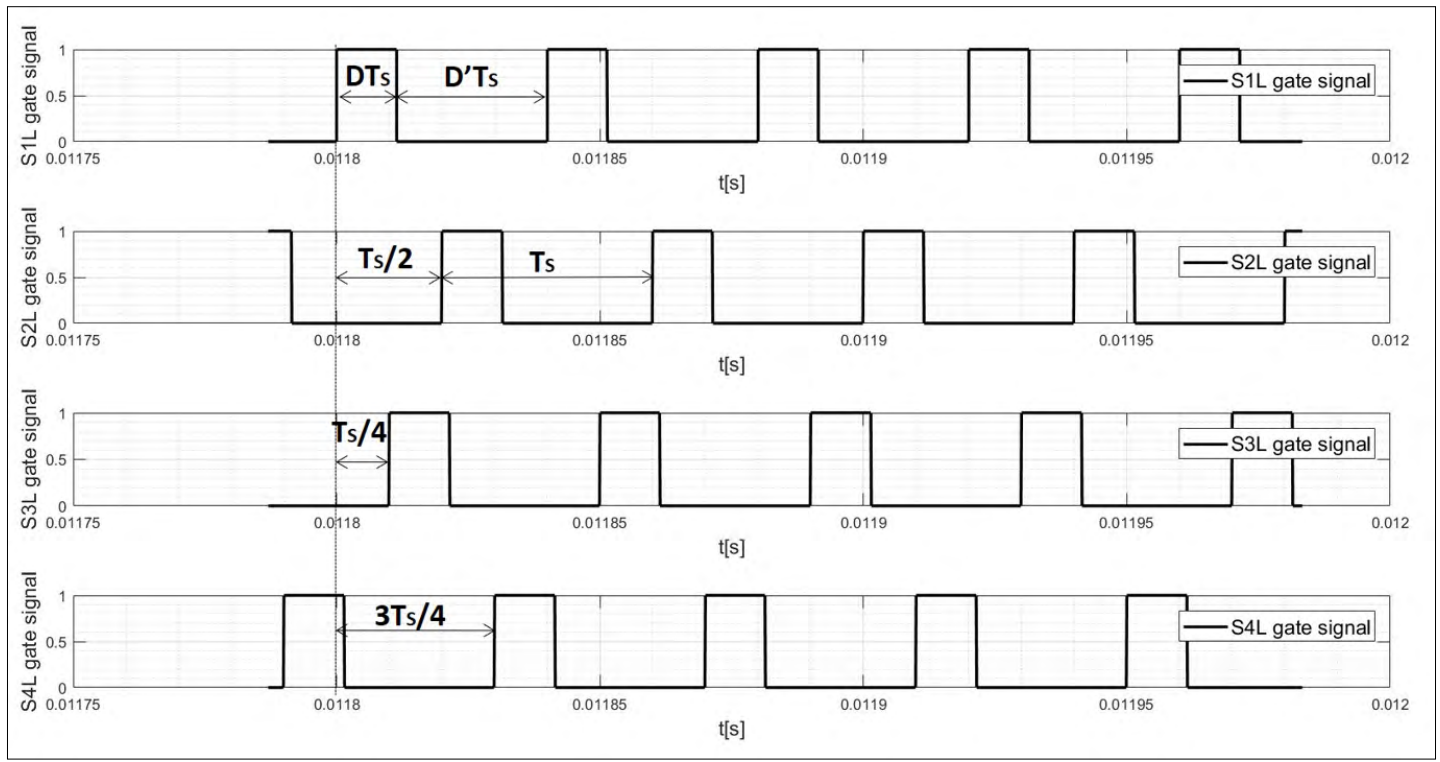

8. ábra. A 4-fázisú átlapolásos vezérlésü DC-DC áramirányító alsó tranzisztorainak a logikai vezérlőjelei

\section{Az aktív párhuzamos HETR teljesít- ménymegosztásának a szabályozása}

Tanulmányozva a nemzetközi szakirodalomban közölt hasonló HETR rendszereket, az 9. ábrán bemutatott szabályozási struktúrát állítottuk össze [12,13,14].Állandósultállapotbanaz5.ábra DC-DC áramirányítói által leadott összteljesítmény a terhelés által felvett teljesítményt kell fedezze. Ha az áramirányítók által leadott teljesítmény kisebb a terhelés által felvett teljesítménynél, ez az EÁKK kondenzátorában tárolt energiának, vagyis az EÁKK feszültségének a csökkenését eredményezi. Ilyen módon a 9. ábrán látható szabályozási struktúra feszültségszabályozójának kimenete tulajdonképpen a DC-DC áramirányítók által az EÁKK-ba bevitt összteljesítmény $P_{\text {el_req }}$ alapjeleként értelmezhető.

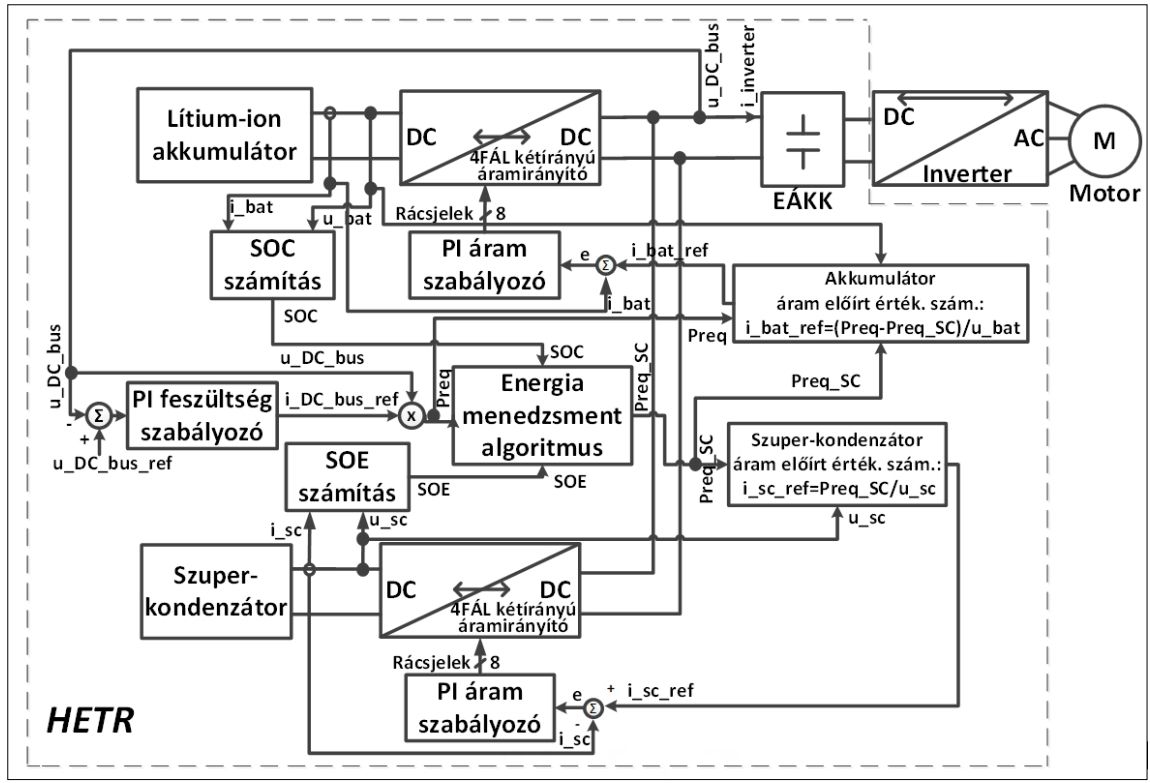

9. ábra. A megmodellezett és szimulált HETR szabályozási struktúrája 
Ezt a feszültségszabályozó által támasztott összteljesítmény-igényt az akkumulátor és a szuperkondenzátor kell kiszolgálja.

Az aktív párhuzamos HETR energiamenedzsment-algoritmus határozza meg azt a $P_{\text {req_sc }}$ pillanatnyi teljesítményt, amelyet a szuperkondenzátornak kell biztosítania úgy, hogy az akkumulátor ne károsodjék. Az egyes energiaforrások teljesítményreferenciái az alábbi összefüggések szerint számíthatók:

$$
\left\{\begin{array}{c}
x=\frac{P_{\text {req_SC }}}{P_{\text {el_req }}} 100 \\
P_{\text {req_BAT }}=P_{\text {el_req }}-P_{\text {req_SC }}
\end{array},\right.
$$

ahol $x$ százalékban a $P_{\text {req_sc }}$ részaránya az igényelt összteljesítményből.

Regeneratív fékezési üzemmódban a $P_{\text {el_req }}$ negatív, mivel a villamos gép által az EÁKK-ba visszatermelt energia a kondenzátorfeszültség növekedését eredményezné, aminek megakadályozása csak a többletenergiának a szuperkondenzátorba, illetve az akkumulátorba való visszatermelésével lehetséges.

$\mathrm{Az}$ áramalapjelek értékeinek a meghatározása az energiamenedzsment-algoritmus által előírt teljesítménymegosztás és a két energiatároló feszültségszintjének az ismeretében történik:

$$
\left\{\begin{array}{c}
i_{S C_{-} R E F}=\frac{x}{100} \frac{P_{e l_{\_} r e q}}{U_{S C}} \\
i_{B A T_{\_} R E F}=\frac{100-x}{100} \frac{P_{e l_{\_} r e q}}{U_{B A T}}
\end{array},\right.
$$

ahol $U_{S C}$ és $U_{B A T}$ a szuperkondenzátor, illetve az akkumulátor feszültsége.

\section{Az aktív párhuzamos HETR szimulá- ciói}

A bemutatott HETR rendszer (5. ábra) és a szabályozási struktúrája (9. ábra) modellezését és szimulációját MATLAB/Simulink ${ }^{\circledR}$ környezetben végeztük el.

A 10. és 11. ábra ugyanannak a szimulációnak az eredményeit mutatja be. A szimulációban az EÁKK-ra csatlakoztatott villamos hajtást egy

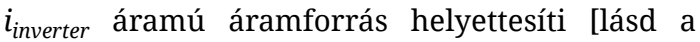
10. ábra a) diagramját]. A 10. ábra b) diagramja az $u_{D C_{\text {b bus }}}=50$ Vra szabályozott EÁKK feszültségváltozását szemlélteti menet-, illetve regeneratív fékezési üzemmódokban. A 11. ábra a $\mathrm{t} \in$ (20ms -55ms) időintervallumban egy $C_{s c}=43 \mathrm{~F}$ kapacitású, $u_{s c}=32 \mathrm{~V}$ kezdeti feszültségre feltöltött szuperkondenzátor konstans árammal $\left(i_{s c}=-5 \mathrm{~A}\right)$ történő töltését szemlélteti a 10. ábra d) diagramja szerint, ami $P_{\text {req_sc }} \approx-150 \mathrm{~W}$ „negatív” szuperkondenzátor-teljesítményt eredményez [lásd a 11. ábra c) diagramját].

A szuperkondenzátor töltése az akkumulátorról történik az EÁKK-re csatlakozó két DC-DC áramirányítón keresztül, a 11. ábra b) és c) diagramjainak megfelelően.

A $t \in(70 \mathrm{~ms}, 96 \mathrm{~ms})$ időintervallumban a HETR energiaforrásként működik, és az áramszabályozott DC-DC áramirányítók pozitív árammal fedezik a fogyasztó által felvett teljesítményt (lásd a 10. ábra c) és d) diagramját) úgy, hogy a teljesítménymegosztás az akkumulátor és a szuperkondenzátor között az energiamenedzsment-algo-

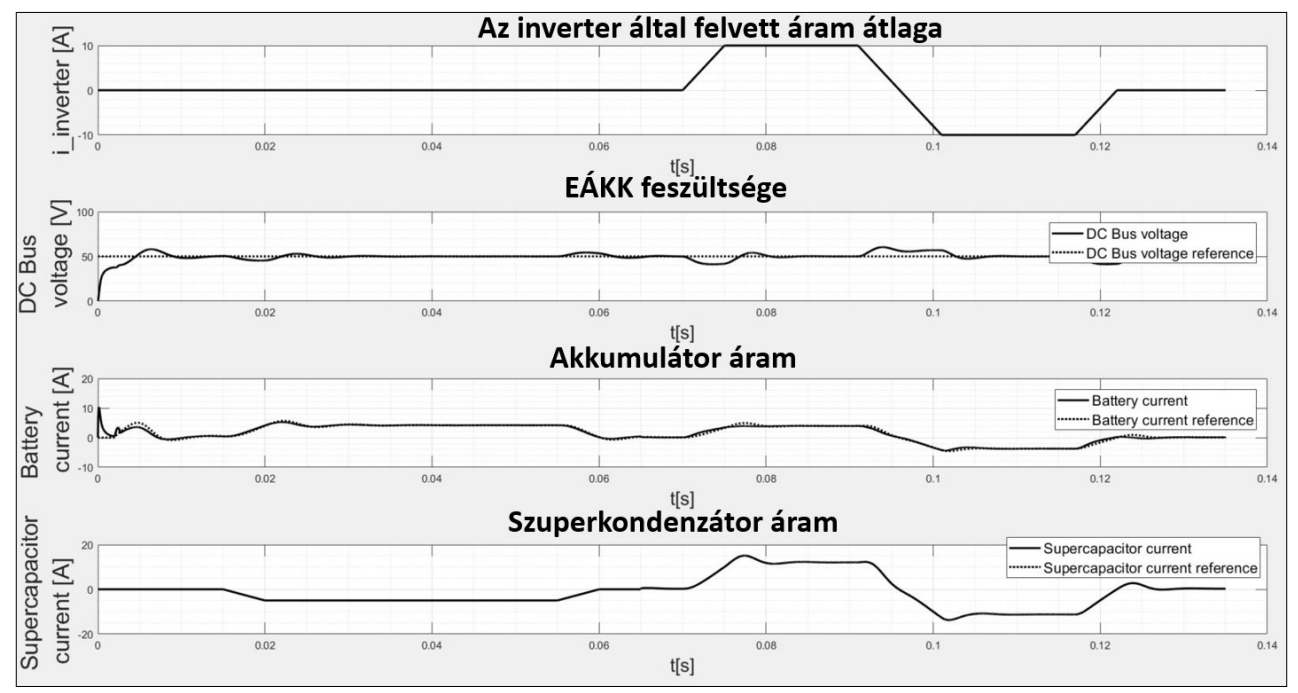

10. ábra. Szimulációs eredmények: Az EÁKK $i_{\text {inverter }}$ bemeneti árama (a) és feszültsége (b), valamint a két energiaforrás árama: az akkumulátoré (c) és a szuperkondenzátoré (d). 


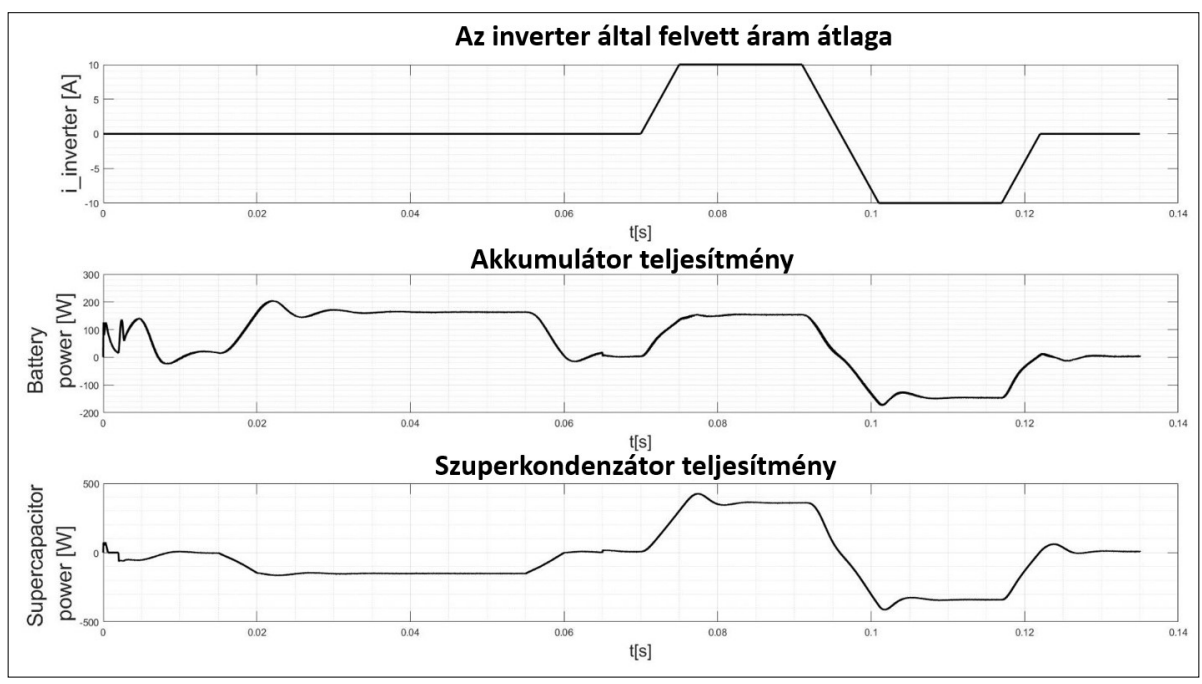

11. ábra. Szimulációs eredmények a HETR két üzemmódjának szemléltetésére: a két energiaforrás közötti teljesítménymegosztás alakulása az $i_{\text {inverter }}$ terhelö áram (a) hirtelen változása következtében a $t=70 \mathrm{~ms}$ és $t=92 \mathrm{~ms}$ pillanatokban, illetve a szuperkondenzátor (c) akkumulátorról (b) történö töltése alatt (20 ms-55 ms között).

ritmus által éppen előírt 3/7 arányban történjen [lásd a 11. ábra b) és c) diagramját].

Ebben az esetben a szimuláció $u_{b a t}=36 \mathrm{~V}$ és $u_{s c}=20 \mathrm{~V}$ feltétellel történt.

A t $\in$ (96 ms, 122 ms) időintervallumban a HETR energiatárolóként működik, ugyanis az áramszabályozott DC-DC áramirányítók negatív árama azt jelenti, hogy a hibrid energiaforrás felveszi az inverteren keresztül a fogyasztó által visszatermelt teljesítményt. Ezt a 10. ábra c) és d) diagramjai és 11. ábra b) és c) diagramjai szemléltetik.

A $t \in(0 \mathrm{~ms}, 12 \mathrm{~ms})$ időintervallumban a terhelés nulla, és a DC-DC áramirányítók betáplálását követően azok csak az EÁKK $C_{D C}=200 \mu \mathrm{F}-$ os kondenzátorának feltöltését kell biztosítsák.

A következőkben egy villamos kerékpár szimulációját mutatjuk be, melynek az energiaellátása a tervezett HETR-ről történik. A kerékpár szimulációját egy valós versenykerékpár paramétereivel végeztük el [15]. Az igényelt maximális villamos teljesítmény $\left(P_{\text {el_req }}\right)$ meghatározásához kiszámítottuk a (2)-vel a jármüre ható erőket.

Az $F_{\text {air }}=10.32 \mathrm{~N}$ légellenállási erőt a $\rho=1,18 \mathrm{~kg} / \mathrm{m}^{3}$, $C_{d}=0,88, A_{\text {front }}=0,362 \mathrm{~m}^{2}$, és $v=7,41 \mathrm{~m} / \mathrm{s}$ paraméterekkel határoztuk meg.

A súrlódási erő $\left(F_{\text {friction }}\right)$ számításánál használt paraméterek a következők voltak: a jármü tömege $m=100 \mathrm{~kg}$ (25 $\mathrm{kg}$ a kerékpár, illetve a rajta ülő személy $75 \mathrm{~kg}), \mu=0,003, g=9,81 \mathrm{~m} / \mathrm{s}^{2}$ és $\cos \alpha=1$. Az $F_{\text {inertial }}=25 \mathrm{~N}$ tehetetlenségi erőt az $a_{\text {vehicle }}=0,25 \mathrm{~m} / \mathrm{s}^{2}$ gyorsulással számoltuk ki. A maximális hajtóerő $F_{\text {traction }}=37.97 \mathrm{~N} \mathrm{az}$ $r_{\text {wheel }}=0,3429 \mathrm{~m}$ sugarú keréken $T_{\text {wheel }}=13 \mathrm{Nm}$ forgatónyomatékot hoz létre. A maximális teljesítmény értéke, amelyet a fenti paraméterekkel a villamos gépnek biztosítania kell, az $P_{\text {el_req }}=281 \mathrm{~W}$.

A 12. ábra diagramjai az általunk megválasztott vezetési ciklus sebesség- (a) és gyorsulási (b) profilját szemlélteti. A gyorsulási folyamat alatt a villamos kerékpár álló helyzetből indulva
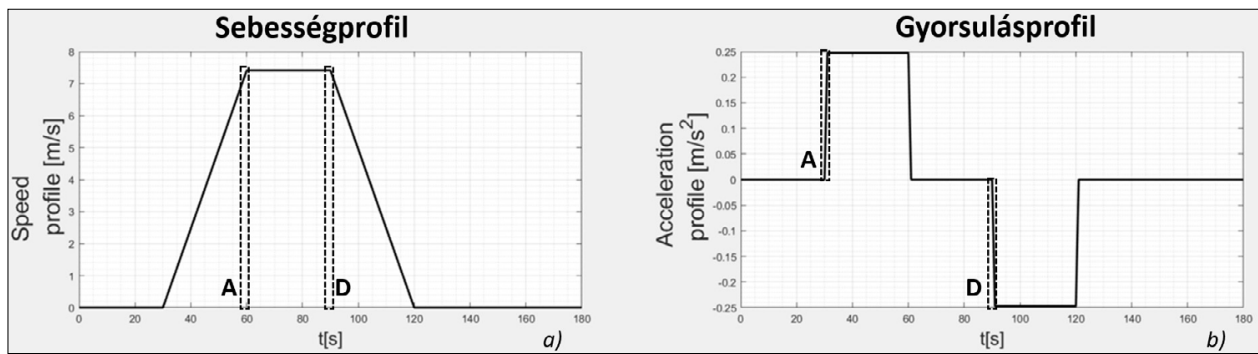

12. ábra. Az általunk meghatározott vezetési profil a villamos kerékpár gyorsításának és regeneratív fékezésének a szimulációjához: a) a sebességprofil és b) a gyorsulási profil. 
$0 \mathrm{~m} / \mathrm{s}$-ról, $0,25 \mathrm{~m} / \mathrm{s}^{2}$ gyorsulással, 7,41 m/s sebességet ér el. Fékezéskor a kerékpár $-0,25 \mathrm{~m} / \mathrm{s}^{2}$-tel (negatív gyorsulással) lassul a megadott állandó sebességről a megállásig.

A következőkben bemutatott szimulációs eredményekkel a teljesítménymegosztást a csúcsteljesítményekre szemléltetjük, az A és D zónából kiragadott $t_{2}-t_{1}=43 \mathrm{~ms}$, illetve $t_{4}-t_{3}=55 \mathrm{~ms}$ időintervallumokban, amikor a teljesítménymegosztás állandósul. Gyorsuláskora HETR szuperkondenzátora $S O E=95 \%$, illetve az akkumulátora $S O C=95 \%$ kezdeti értékekre vannak feltöltve.

A 13. ábra szimulációs eredményei a villamos kerékpár gyorsulási folyamatában az EMA által meghatározott teljesítménymegosztás időbeli alakulását mutatják be (az akkumulátor és a szuperkondenzátor között), a gyorsulási folyamat végén és a rendszer állandósult állapotában, a 12. ábrán az A-val megjelölt (szaggatott vonallal bekeretezett) zónában. Gyorsításához a HETR-nek $\approx 281 \mathrm{~W}$ csúcsteljesítményt kell biztosítania, amikor energiaforrásként üzemel.

A jelzett időintervallumban a fuzzy-szabályalapú EMA x = 88\%-os energiamegosztási arányt határozott meg.
A teljesítménymegosztást a 9. ábrán bemutatott szabályozó struktúra végzi el, miszerint a szuperkondenzátor $\approx 240 \mathrm{~W}$, illetve az akkumulátor ₹34 W teljesítménnyel járul hozzá a teljesítményigény kielégítéséhez, mint ahogyan a 13. ábra a) és b) diagramjain látható.

A 14. ábra szimulációs eredményei a villamos kerékpár regeneratív fékezési folyamatában az EMA által meghatározott teljesítménymegosztás időbeli alakulását mutatják be (az akkumulátor és a szuperkondenzátor között), a fékezési folyamat kezdetén és a rendszer állandósult állapotában, a 12. ábrán a D-vel megjelölt (szaggatott vonallal bekeretezett) zónában. Fékezéskor a HETR szuperkondenzátora $S O E=50 \%$, illetve az akkumulátora $S O C=95 \%$ kezdeti értékekre vannak feltöltve. A kerékpár regeneratív fékezése során a HETR $\approx-89$ W csúcsteljesítményen kell tárolja a generált energiát, a fuzzy-szabályalapú EMA $\mathrm{x}=72 \%$ energiamegosztási arányt határoz meg az akkumulátor és a szuperkondenzátor között, ami $\approx-26 \mathrm{~W}$, illetve $\approx-64 \mathrm{~W}$ feltöltési teljesítménynek felel meg, mint ahogyan a 14. ábra a) és b) diagramjain megfigyelhető.
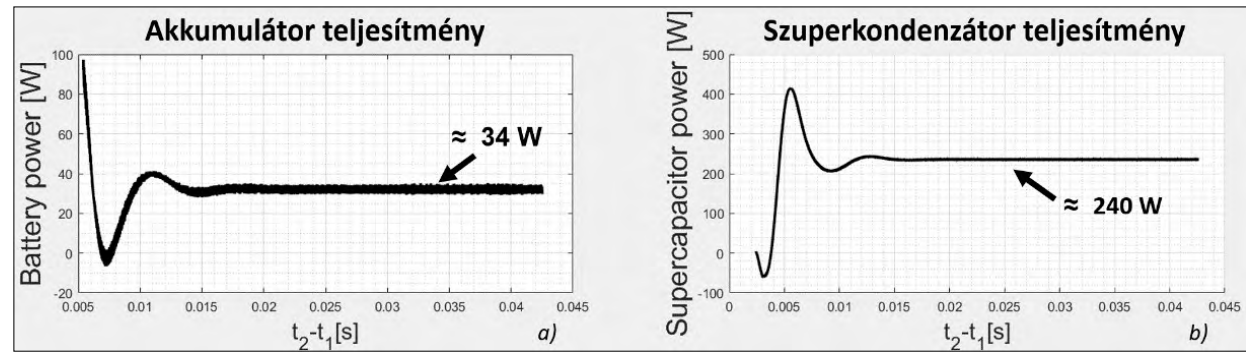

13. ábra. Villamos kerékpár gyorsitási folyamatának a szimulációs eredménye a gyorsitás végén, a 12. ábra diagramjainak az A-val megjelölt bekeretezett részén, a $t_{2}-t_{1}=43$ ms időtartományban: a) az akkumulátor által szolgáltatott teljesítmény időbeli változása; b) a szuperkondenzátor által biztosított teljesítmény időbeli változása.
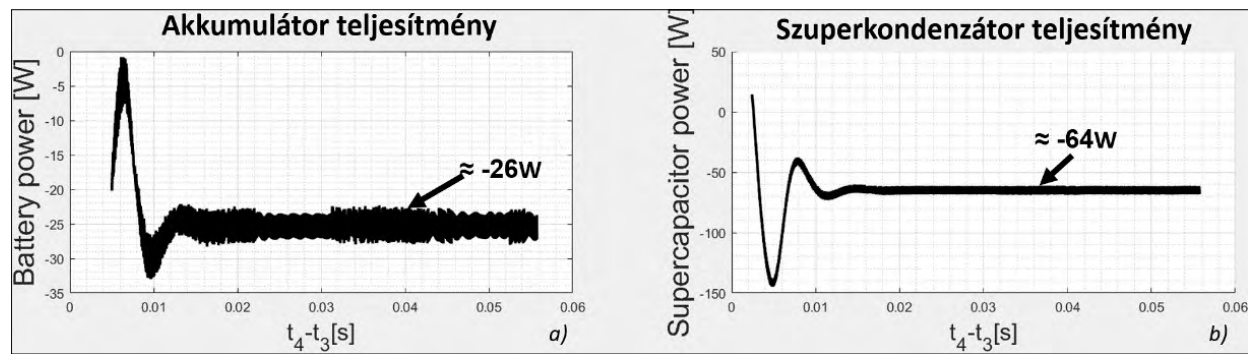

14. ábra. Villamos kerékpár regenerativ fékezésének a szimulációs eredménye a fékezési folyamat kezdetén, a 12. ábra diagramjainak a $D$-vel megjelölt bekeretezett részén, $t_{4}-t_{3}=55 \mathrm{~ms}$ időtartományban: $a$ ) az akkumulátor által szolgáltatott teljesítmény időbeli változása; b) a szuperkondenzátor által biztosított teljesítmény időbeli változása. 


\section{Következtetések}

A megtervezett fuzzy szabályalapú EMA úgy osztja meg a teljesítményt, hogy az akkumulátor károsodása elkerülhető legyen.

A bemutatott szimulációs eredmények alátámasztják a kétirányú, átlapolásos vezérlésű DC-DC áramirányítókkal felépített HETR szabályozási struktúrájának a működőképességét.

A szimulációk során felhasznált paraméterek megfelelnek egy, a jövőben gyakorlati kivitelezésre szánt, 0,5 kW teljesítményü villamos kerékpár hajtását tápláló hibrid energiatároló rendszernek, amelyen a megtervezett fuzzy szabályalapú EMA-t szándékunkban van implementálni.

\section{Szakirodalmi hivatkozások}

[1] S. M. Lukic, J. Cao, R. C. Bansal, F. Rodriguez, A. Emadi: Energy Storage Systems For Automotive Applications. IEEE Trans. on Industrial Electronics, 55/6. (2008) 2258-2267. https://doi.org/10.1109/TIE.2008.918390

[2] Ferencz J., Kelemen A., Imecs M.: Hibrid energiatároló rendszer energiamenedzsmentje. In: XXI. Energetika-Elektrotechnika - ENELKO és XXX. Számítástechnika és Oktatás - SzámOkt Multi-konferencián. EMT, Kolozsvár, 2020. 40-45. https://ojs.emt.ro/index.php/enelko-szamokt/article/view/315/255

[3] H. Yu, F. Cheli, F. Castelli-Dezza, D. Cao, F.-Y. Wang: Multiobjective Optimal Sizing and Energy Management of Hybrid Energy Storage System for Electric Vehicles.

https://www.researchgate.net/publication/322652476_Multi-objective_Optimal_Sizing_and_Energy_Management_of_Hybrid_Energy_Storage_System_for_Electric_Vehicles

[4] Maarten J. van Jaarsveld, Rupert Gouws: An active hybrid energy storage system utilizing a fuzzy logic rule-based control strategy. World Electric Vehicle Journal, 2020/4. 1-24. https://doi.org/10.3390/wevj11020034

[5] Zhang Q., Deng W., Zhang S., Wu J.: A rule based energy management system of experimental battery/supercapacitor hybrid energy storage system for electric vehicles. Journal of Control Science and Engineering, 2016. 1-17. https://doi.org/10.1155/2016/6828269

[6] Guzzella L., Amsutz A.: The QSS Toolbox Manual. Swiss Federal Institute of Technology Zurich (ETH Zürich), Measurement and Control Laboratory, June 2005.
[7] Ehsani M., Gao Y., Gay E. S., Emadi A.: Modern Electric, Hybrid Electric, and Fuel Cell Vehicles. 4. Ed., CRC Press, Boca Raton, London, New York, Washington D.C., 2005. 21-34.

[8] J. Cao, A. Emadi: A New Battery/UltraCapacitor Hybrid Energy Storage System for Electric, Hybrid, and Plug-In Hybrid Electric Vehicles. IEEE Transactions on Power Electronics, 27/1. (2012) 122-132.

https://doi.org/10.1109/TPEL.2011.2151206

[9] Ferencz J., Kelemen A., Imecs M.: Aktív párhuzamos hibrid energiatároló rendszer áramirányitóinak a szabályozása. In: XXI. Energetika-Elektrotechnika - ENELKO és XXX. Számítástechnika és Oktatás - SzámOkt Multi-konferencián. EMT, Kolozsvár, 2020. 34-39.

https://ojs.emt.ro/index.php/enelko-szamokt/article/view/316/254

[10] Yu W., Lai J. S.: Ultra high efficiency bidirectional $D C-D C$ converter with multi-frequency pulse width modulation. In: Proceedings: APEC 2008 Twenty-third Annual IEEE Applied Power Electronics Conference and Exposition, Austin, Texas, 2008. Piscataway, N.J., IEEE, 1079-1084

https://doi.org/10.1109/APEC.2008.4522856

[11] Kanta S., Plangklang B., Subsingha W.: Design of a Bi-directional DC-DC 4 Phase Interleave Converter for PV Applications. Energy Procedia, 56. (2014) 604-609.

https://doi.org/10.1016/j.egypro.2014.07.199

[12] Dulout J., Jammes B., Séguier L., Alonso C.: Control and design of a hybrid energy storage system. In: Proceedings of the $201517^{\text {th }}$ Conference on Power Electronics and Applications (EPE '15 ECCE-EUROPE 2015), Geneva, Switzerland, 2015. Institute of Electrical and Electronics Engineers (IEEE), 2016. 1-9.

[13] Manandhar U., Ukil A., Kollimalla S. K., Gooi H. B. L.: Application of HESS for PV system with modified control strategy. In: 2015 IEEE Innovative Smart Grid Technologies - Asia (ISGT ASIA), Bangkok, Thailand, IEEE, 2015. 1-6. https://doi.org/10.1109/ISGT-Asia.2015.7387078

[14] M. B. Camara, H. Gualous, F. Gustin, A. Berthon: Design and New Control of DC/DC Converters to Share Energy Between Supercapacitors and Batteries in Hybrid Vehicles. IEEE Transactions on Vehicular Technology, 57/5.(2008) 1-15. https://doi.org/10.1109/TVT.2008.915491

[15] Wilson D. G.: Bicycling Science. 3. ed. MIT Press, Cambridge, Massachusetts, London, England, 2004. 188-209. 